The Southeast Asian Journal of Midwifery Vol. 4, No.1, March, 2018, p: 32-39

E-ISSN: 2476-9720

P-ISSN: 2476-9738

\title{
Factors Associated with Basic Immunization Status of Infants
}

\author{
Dewi Novitasari Suhaid ${ }^{1}$, Fransisca Faranita ${ }^{2}$ \\ 1,2 Midwifery Diploma Program, Sint Carolus School of Health Sciences
}

\begin{tabular}{|c|c|}
\hline ARTICLE INFORMATION & A B S T RA C T \\
\hline $\begin{array}{l}\text { Article Trace: } \\
\text { Submission: January 02, } 2018 \\
\text { Final Revision: March 12, } 2018 \\
\text { Available online: March 20, } 2018 \\
\end{array}$ & $\begin{array}{l}\text { Immunization is an attempt to actively boost a person's immunity against } \\
\text { a disease, so that if one day exposed to the disease will not get sick or just } \\
\text { experience mild illness. Immunization is routinely divided into primary } \\
\text { immunization and continued immunization. Basic immunization is given }\end{array}$ \\
\hline $\begin{array}{l}\text { Key word: } \\
\text { Basic immunization of infants, occupation, } \\
\text { education, knowledge, attitude }\end{array}$ & $\begin{array}{l}\text { to infants aged } 0 \text { to } 1 \text { year, where as advanced immunization is a repeat } \\
\text { immunization intended to maintain immunity level or to prolong the } \\
\text { period of protection. Further immunization is given when primary } \\
\text { immunization is given first, and is given at the age of toddlers and at } \\
\text { school age. }\end{array}$ \\
\hline $\begin{array}{l}\text { Contact: } \\
\text { dewinovitasari@gmail.com }\end{array}$ & $\begin{array}{l}\text { This research is cross-sectional study. The dependent variable in this } \\
\text { study is the basic immunization status of infants, while the independent } \\
\text { variables include age, education level, occupation, knowledge and } \\
\text { attitude. The sample of this research is mothers with children aged } 12-24 \\
\text { months totaling } 250 \text { respondents. Instrument of data collection using } \\
\text { questionnaire and health record of baby. The data transformation uses the } \\
\text { data normality test and Rasch model. Data analysis technique using Chi } \\
\text { Square test and logistic regression test. } \\
\text { The result of data analysis showed that there was a significant correlation } \\
\text { between occupation }(\mathrm{p}<0,05, \mathrm{PR}=1,864 ; 95 \% \mathrm{CI}=1,121-3,097) \text {, } \\
\text { education level }(\mathrm{p}<0,05 ; \mathrm{PR}=3,438 ; 95 \% \mathrm{CI}=1,671-7,074), \text { knowledge } \\
\text { (p }<0,05, \mathrm{PR}=2,653 ; 95 \% \mathrm{CI} 1,580-4,455) \text { and attitude (p }<0,05 \text {, PR }= \\
3,202 ; 95 \% \mathrm{CI}=1,897-5,405) \text { with infant immunization status. Age has } \\
\text { no significant relationship with the basic immunization status of infants. } \\
\text { Conclusions coverage of basic infant immunization completeness in this } \\
\text { area is still low that is equal to } 42,4 \% \text {. Attitude is the most dominant } \\
\text { factor associated with the basic immunization status of infants. }\end{array}$ \\
\hline
\end{tabular}




\section{BACKGROUND}

Progress of a country is built through strategies to improve human resources through improved health and welfare. Associated with development in the health sector then the strategy is formulated through government policy with one of the agenda of work is "Sustainable Development Goals (SDGs)". There are seventeen success indicators of SDGs that target zero goals for all indicators, specifically for the health sector focusing on reducing maternal mortality, infant mortality and underfive mortality with each target of 70 per $100,000 \mathrm{KH}, 12$ per $1,000 \mathrm{KH}$ and 25 per $1,000 \mathrm{KH}$ by 2030 .

The high rate of infant mortality in Indonesia is caused by diseases that can be prevented by immunization, including Tuberculosis, Diphtheria, Pertussis, Tetanus, Hepatitis B, Polio and Measles. An estimated 1.7 million $(5 \%)$ of deaths in infants can be prevented by immunization.

Immunization is an attempt to actively boost a person's immunity against a disease, so that if one day exposed to the disease will not get sick or just experience mild illness. Immunization is routinely divided into primary immunization and continued immunization. Basic immunization is given to infants aged 0 to 1 year, whereas advanced immunization is a repeat immunization intended to maintain immunity level or to prolong the period of protection. Further immunization is given when primary immunization is given first, and is given at the age of toddlers and at school age.

Immunization should be known by every family and community, about 3 out of 100 births of children will die of measles, 2 out of 100 births of children will die of whooping cough, 1 in 100 births of children die of tetanus disease. And of every 200,000 children, 1 will suffer from polio disease. Immunization done by giving a particular vaccine will protect the child against certain diseases. Although vaccination facilities are now available in the community, but not all infants are brought in for complete immunization.
The government policy of $0-11$ months of age is mandatory for complete basic immunization consisting of 1 dose of Hepatitis B, 1 dose of BCG, 3 doses of DPT-Hepatitis B, 4 polio doses, and 1 dose of measles. Percentage of immunization by its highest to present lows in Indonesia is BCG (77.9\%), Measles (74.4\%), Polio 4 (66.7\%), and lowest DPT-HB 3 $(61.19 \%)$. For national and global targets to achieve eradication, elimination and reduction of PD3I, immunization coverage should be maintained high and evenly until it reaches a high level of population immunity. Efforts are made to help the achievement of growth and infant health to adult high quality. According to WHO data about 194 developed and developing countries continue to perform routine immunization in infants and children . Developed countries with good levels of nutrition and the environment continue to routinely immunize all of their babies, as they are proven beneficial to immunized infants and prevent the spread of surrounding children. Every years about $85-95 \%$ of babies in those countries are routinely immunized, while the remainder have not been immunized because of certain diseases, access to immunization services, distance barriers, geographic, security, socio-economic and so on. Immunization is not only a health program in Indonesia but also a world program (WHO). There is no vaccine or drug that is $100 \%$ safe from risk factors, but in general, safe immunization is given, even the benefits provided are very large compared to existing risk factors.

The purpose of this study was to analyze factors related to the basic immunization status of infants including age, occupation, education level, knowledge and attitude. The final result is also expected to know the dominant factors most related to the basic immunization status of infants.

\section{METHOD}

This research uses observational, analytic, cross-sectional design. The dependent variable in this study is the basic immunization status of infants, while the independent variables include age, education level, occupation, 
knowledge and attitude. The research was conducted in Alamendah Village, Rancabali, Bandung Regency, West Java in OctoberNovember 2017. The sample of this research is mothers with children aged 12-24 months totaling 250 respondents. The sample was chosen by consecutive sampling method. The data used are primary data to measure the independent variable and secondary data to measure the dependent variable. Instrument of data collection using questionnaire and health record of baby. The questionnaire contains questions about the level of knowledge of 20 items and the question of attitude totaling 10 items, both measured by likert scale. The instrument has passed the test stages of validity and reliability with Product Moment test for validity test and Cronbach's Alpha test. The reliability test analysis earns a value of 0.873 .

Data analysis using computerized system. Age variable, education and occupation are categorical data, while knowledge and attitude is variable with numerical data which will be transformed into categorical data. The knowledge variable is transformed by using cut-off point average value because the data form of normal distributed knowledge variable. Attitude variables were analyzed with Rasch model which then used cut off point average logit value for transformation into categorical data. Bivariate analysis using chi square test and multivariate analysis using logistic regression test

\section{RESULTS}

The research has been conducted on 250 selected respondents with the research procedure through the agreement to fill informed consent and answer the questionnaire available

\section{Table 1. Results Transformation of Knowledge and Attitude Variables}

\begin{tabular}{ll}
\hline Variable & Cut off Point \\
\hline Knowledge & Mean $=14,7^{*}$ \\
Attitude & Mean (Logit) $=79,89^{* *}$ \\
& $\mathrm{SD}=20,26$ \\
\hline
\end{tabular}

* Distribution of normal data by Shapiro Wilk analysis

** Analysis with Rasch model

Based on Table 1 it is known that the result of the transformation of the original knowledge variable is numerical data into categorical data using the average value with the consideration that the data distribution is quite normal. The result of the transformation of knowledge variables obtained the measurement of less knowledge and good knowledge. Transformation of attitude variable using Rasch model analysis, got the average value of logit 79,89 so categorizing attitude variable got result of 2 scale measure that is not support attitude and support attitude 
Table 2. Frequency Distribution of Immunization Status of Infant, Age, Occupation, Level of Education, Knowledge and Attitude

\begin{tabular}{lll}
\hline Variable & Amount (n) & Percentage (\%) \\
\hline basic immunization status of infants & 106 & 42,4 \\
complete & 144 & 57,6 \\
incomplete & & \\
Age & 76 & 30,4 \\
$<\mathbf{2 0}$ years and or $>\mathbf{3 5}$ years & 174 & 69,6
\end{tabular}

\begin{tabular}{lcc} 
Occupation & 124 & 49,6 \\
No working & 126 & 50,4 \\
Working & 198 & \\
\hline Level of education & 52 & 79,2 \\
Basic education & 126 & 20,8 \\
High education & 124 & 50,4 \\
\hline Knowledge & & 49,6 \\
Less & 122 & \\
Good & 128 & 48,8 \\
\hline Attitude & & 51,2 \\
\hline Does not support & & \\
\hline Support & & \\
\hline
\end{tabular}

Based on table 2 it is known that the description of immunization status in Alamendah Village, Rancabali, Bandung Regency West Java in the year 2017 is mostly have incomplete status (57.65). Most 69.6\% of respondents are in the productive age range with a minimum health risk of 20-35 years. Most of the $50.4 \%$ of respondents work, with the results of further study that the work of respondents, among others, are farmers and farm laborers. $79.2 \%$ of respondents are primary education level. Based on the Indonesian government regulations that the category of basic education is education up to the first 9 years is up to the range of junior high school education. Respondents' knowledge is mostly $50.4 \%$ in less categories, and $51.2 \%$ of respondents support to provide their children with basic immunization set by the government. 
Table 3. Relationship of Age, Occupation, Education Level, Knowledge and Attitude With Basic Immunization Status of Infant

\begin{tabular}{|c|c|c|c|c|}
\hline \multirow[b]{2}{*}{ Variable } & \multicolumn{2}{|c|}{ Immunization Status } & \multirow[b]{2}{*}{$P$ value } & \multirow[b]{2}{*}{$\begin{array}{l}P R \\
(95 \% \mathrm{CI})\end{array}$} \\
\hline & $\begin{array}{l}\text { Incomplete } \\
(\mathrm{n}=144)\end{array}$ & $\begin{array}{l}\text { Complete } \\
(n=106)\end{array}$ & & \\
\hline \multicolumn{3}{|l|}{ Age } & \multirow{3}{*}{0,621} & \multirow{3}{*}{$\begin{array}{l}1,147 \\
(0,666-1,975)\end{array}$} \\
\hline$<20$ years and or $>35$ years & $34(44,7 \%)$ & $42(55,3 \%)$ & & \\
\hline $20-35$ years & $72(41,4 \%)$ & $102(58,6 \%)$ & & \\
\hline \multicolumn{4}{|l|}{ Occupation } & \multirow{3}{*}{$\begin{array}{l}1,864 \\
(1,121-3,097)\end{array}$} \\
\hline No working & $62(50 \%)$ & $62(50 \%)$ & 0,016 & \\
\hline Working & $44(34,9 \%)$ & $82(65,1 \%)$ & & \\
\hline \multicolumn{3}{|l|}{ Level of education } & \multirow{3}{*}{0,000} & \multirow{3}{*}{$\begin{array}{l}3,438 \\
(1,671-7,074)\end{array}$} \\
\hline Basic education & $95(48 \%)$ & $103(52 \%)$ & & \\
\hline High education & $11(21,2 \%)$ & $41(78,8 \%)$ & & \\
\hline \multicolumn{3}{|l|}{ Knowledge } & \multirow{3}{*}{0,000} & \multirow{3}{*}{$\begin{array}{l}2,653 \\
(1,580-4,455)\end{array}$} \\
\hline Less & $68(54 \%)$ & $58(46 \%)$ & & \\
\hline Good & $38(30,6 \%)$ & $86(69,4 \%)$ & & \\
\hline \multicolumn{4}{|l|}{ Attitude } & \multirow{3}{*}{$\begin{array}{l}3,202 \\
(1,897-5,405)\end{array}$} \\
\hline Does not support & $69(56,6 \%)$ & $53(43,3 \%)$ & \multirow[t]{2}{*}{0,000} & \\
\hline Support & $37(28,9 \%)$ & $91(71,1 \%)$ & & \\
\hline
\end{tabular}

Based on the analysis presented in Table 3 it is known that from the 5 factors studied, it was found that there was only one factor that did not have a significant relationship to the basic immunization status of the infant is the age factor. Although the picture of most respondents are in the productive age is in the range of 20-35 years, but the results of the analysis in the table with the distribution of categories of completeness immunization status found that $41.4 \%$ of mothers who are in the age range 20-35 years do not provide complete immunization to the baby.

The data contained in Table 3 shows that the working mother group has a larger amount to provide complete basic immunization to the baby (65.1\%). In line with the description, the result of bivariate analysis with $95 \%$ confidence level shows the result that unemployed mother has opportunity to not give complete basic immunization to the baby equal to 1,8 times compared with working mother.
The strength of exposure to educational level factors on the basic immunization status of infants is 3.4 times, which means that mothers with education up to the primary education limit have a chance of 3.4 times not to provide complete immunization to their babies. It also affects simultaneously to the knowledge factor. Mothers with less knowledge about immunization will have a 2.6 times greater chance of not fully immunizing their babies. A final analysis of attitude factors showed that mothers who showed no supportive attitude toward immunization had an opportunity of 3.2 times not to provide complete immunization to their infants. 
Table 4. Logistic Regression Analysis of Work, Level of Education, Knowledge and Attitudes With Basic Baby Immunization Status

\begin{tabular}{|c|c|c|c|c|c|}
\hline Variable & Koef $(\beta)$ & SE ( $\beta)$ & Wald & P value & $\begin{array}{ll}\text { Exp.B } & (95 \% \\
\text { CI) } & \end{array}$ \\
\hline High education & 1,341 & 0,397 & 11,388 & 0,001 & $\begin{array}{l}3,821 \quad(1,754- \\
8,324)\end{array}$ \\
\hline Working & 0,831 & 0,296 & 7,876 & 0,005 & $\begin{array}{l}2,295 \quad(1,285- \\
4,100)\end{array}$ \\
\hline Good knowledge & 1,157 & 0,295 & 15,379 & 0,000 & $\begin{array}{l}3,181 \\
5,671)\end{array}$ \\
\hline Support attitude & 1,361 & 0,299 & 20,780 & 0,000 & $\begin{array}{l}3,902 \quad(2,173- \\
7,006)\end{array}$ \\
\hline Constanta & $-3,125$ & 0,508 & 37,807 & 0,000 & \\
\hline
\end{tabular}

* Analysis with logistic regression

\section{DISCUSSION}

Immunization is one of the prevention efforts that can be done to prevent the spread of disease and is an indicator of the health status of children in a country. Despite the significant benefits to immunization as a pre-emptive effort, however, especially in the country of Indonesia there have been various issues affecting parents' decision to immunize their children.

Based on the results of research conducted found that only $42.4 \%$ of children who have complete basic immunization status in accordance with the provisions of the government. This data is very apprehensive when compared with the government target that determines $90 \%$ basic immunization coverage.

The condition is influenced by several factors such as the result of this research is the work, the level of education, knowledge and attitude. Work is closely linked to the economic conditions in which this will affect the mental preparedness of the family in accessing healthcare facilities. In addition, work can provide an individual opportunity to frequently contact with other individuals, exchange information and share experiences with working moms who will have a wide range of relationships and can exchange information with colleagues, so that more exposure to health programs, especially immunization .
The results suggest that there is a significant relationship between the level of education and knowledge of the basic immunization status of infants. This is in line with research that has been done in Angola, Bangladesh, Ethiopia and several other big cities in Indonesia. The level of education affects knowledge. According to Reinberg (2008) it is said that a person's behavior is influenced by the level of education completed successfully related to the increase of information sources that increase knowledge. Green (1980) states that a person's behavior related to health status is influenced by knowledge, attitude, belief as a predisposing factor to it. All of these factors are related to each other and support a person to make decisions to determine what will be given to self or his family.

Compliance with prevention behaviors related to the medical world is a function of beliefs about health, perceived threats, perceptions of immunity, consideration of obstacles or losses (eg cost and time), as well as the benefits of the effectiveness of the medical advice. Good knowledge can influence behavior change. Behavior can be changed by changing knowledge and attitude. Good knowledge can influence attitudes and behavior change. Knowledge is something that is necessary but generally not enough one factor in changing the behavior of individuals or groups. In support of the statement, Notoatmodjo (2010) states that one's actions on health problems will essentially be influenced by one's knowledge of the problem. 
Social and cultural conditions shape attitudes and behaviors that affect health status. In this study almost all respondents embraced Islam and influenced by Sundanese culture. Based on the observation is known that most mothers have a thought to the issue that lately revealed that the issue of vaccination forbidden given because it contains substances that can not be given by a particular religion. Despite having sufficient knowledge but the influence of religious figures and spirituality beliefs have an impact on decisions taken by the family. An emotional life and a person's inclination to act are also key components that shape a person's attitude.

In addition to the factors studied in this study, there are still other factors affecting the completeness of basic immunization of infants: pregnancy visits, postpartum visits, attitudes of health workers, access to health care, family support, counseling, parity, economic status..

\section{CONCLUSION}

The basic immunization status of infants is influenced by several factors related to health behavior. The coverage of basic infant immunization in Desa Alamendah, Rancabali District, Bandung Regency West Java is still low compared to the national indicator of $42.4 \%$. The level of education affects a person's knowledge. Along with this, behavior is also influenced by attitudes that are motivated by tradition and local cultural conditions. Increased knowledge can also be obtained through information from the media and opportunities to chat and exchange information in the social environment and work environment. Based on the result of the research, it is concluded that attitude is the most dominant factor if connected with the completeness of infant immunization status, in addition to work factor, education and knowledge level..

\section{BIBLIOGRAPHY}

Ameen, M. dan Mustafi, A. (2013) "Factor Influencing of Child Immunization in Bangladesh," 1(3), hal. 55-65.

Departemen Kesehatan Republik Indonesia (2014) Peraturan Menteri Kesehatan Republik Indonesia Nomor 42 Tahun 2013 Tentang Penyelenggaraan Imunisasi,
Departemen Kesehatan RI. doi: 10.1007/s13398-014-0173-7.2.

Kementerian Kesehatan RI (2017) Profil Kesehatan Indonesia Tahun 2016. Jakarta. Konstantyner, T. (2011) "Risk Factors For Incomplete Vaccination in Children Less Than 18 Months of Age Attending The Nurseries of Day-Care Centres in Sao Paulo, Brazil," Vaccine, 29(50).

Meleko, A., Geremew, M. dan Birhanu, F. (2017) "Assessment of Child Immunization Coverage and Associated Factors with Full Vaccination among Children Aged 12-23 Months at Mizan Aman Town, Bench Maji Zone, Southwest Ethiopia," International Journal of Pediatrics, 2017, hal. 1-11. doi: $10.1155 / 2017 / 7976587$.

Negussie, A. (2016) "Factors Associated With Incomplete Childhood Immunization in Arbegona District, Southern Ethiopia: a case control study," BMC Public Health, 16.

Nugroho, P. J. (2012) Hubungan Tingkat Pengetahuan, Usia dan Pekerjaan Ibu Dengan Status Imunisasi Dasar Bayi di Desa Japanan Kecamatan Cawas Kabupaten Klaten Tahun 2012. Muhammadiyah Surakarta.

Oleribe, O. et al. (2017) "Individual and socioeconomic factors associated with childhood immunization coverage in Nigeria," Pan African Medical Journal, 26. doi: 10.11604/pamj.2017.26.220.11453.

Oliveira, M. F. (2014) "Factors Associated With Vaccination Coverage in Children $<5$ Years in Angola," Rev Saude Publica, 48(6).

RI, I. dan P. D. K. (2014) Situasi dan Analisis Imunisasi.

Soekidjo, N. (2012) Promosi Kesehatan dan Ilmu Perilaku. Jakarta: Rineka Cipta.

Sofyan, D. (2016) SIARAN PERS: Menteri Sofyan: Indonesia Siap Mengimplementasikan SDGs. Tersedia ada: https://www.bappenas.go.id/id/berita- 
Dewi Novitasari Suhaid, M.Keb1, Fransisca Faranita, SST2

Factors Associated With Basic Immunization Status Of Infants

dan-siaran-pers/siaran-pers-menteri-

sofyan-indonesia-siap-

mengimplementasikan-sdgs/.

Suririnah (2008) Pintar Merawat Bayi 0-12

Bulan. Jakarta: Gramedia Pustaka Utama. 